\title{
KESADARAN FONOLOGI PADA ANAK USIA PRASEKOLAH
}

\author{
K. A. Rahman ${ }^{1}$, Fortuna Mazka ${ }^{2}$, Elmanora $^{2}$
}

\begin{abstract}
Phonological awareness is one of a critical aspect in early literacy development that develop during preschool period. Phonological awareness is sensitivity to the sound structure of language. This study was conducted to analyse the phonological awareness in preschool children. This study was also identify learning activity in the class that support phonological awareness of preschool children. Research with cross sectional design was conducted in AugustNovember 2016 in one kindergarten in Jambi City, Jambi Province, Indonesia. Data were collected through observation, child's performance, and interview with teacher. The collected data were analyzed by descriptive analysis. Result showed that phonological awareness had arisen at the word, syllable, and onset-rime levels. However, children have difficulty in sounding syllables and rime. Teachers have supported the phonological awareness of children through playing and learning activities. However, the activities that has been given to children didn't vary so not all of phonological awareness aspects got sufficient support.
\end{abstract}

Keywords: child learning, early childhood education, phonological awareness

\section{PENDAHULUAN}

Salah satu faktor yang menentukan keberhasilan anak dalam kegiatan pembelajaran adalah membaca. Kemampuan membaca pada anak perlu distimulasi sejak masa kanak-kanak. Dalam mengembangkan kemampuan membaca anak, salah satu faktor yang perlu diperhatikan adalah kesadaran fonologi (Ayriza, 1997). Kesadaran fonologi merupakan aspek yang perlu diperhatikan untuk mengembangkan kemampuan membaca anak terutama pada usia dini yang berada pada proses membaca pada tingkat awal. Kesadaran fonologi merupakan kepekanan menganalisa, menyimpan dan memanipulasi suara dalam suatu bahasa kedalam bagian terkecil dan memetakkannya ke dalam

1 Dosen Program Studi Administrasi Pendidikan, Fakultas Keguruan dan Ilmu Pendidikan, Universitas Jambi, Muaro Jambi, 36361, Indonesia

2 Program Studi Pendidikan Guru Pendidikan Anak Usia Dini, Fakultas Keguruan dan Ilmu Pendidikan, Universitas Jambi, Muaro Jambi, 36361, Indonesia tulisan. Pada masa kanak-kanak awal, anak mulai dikenalkan dengan bunyi dan huruf yang pada tahapan selanjutnya dilakukan peningkatan kemampuan anak dalam membaca kata, kalimat, bahkan paragraf.

Kemampuan ini penting bagi penggunaan pengetahuan huruf dan bunyi secara efektif dalam membaca dan menulis. Faktanya, tingkatan kesadaran fonologi anak di akhir taman kanak-kanak (TK) merupakan salah satu prediktor bagi kesuksesan membaca di masa depan, di kelas satu dan selanjutnya. Selaras dengan apa yang di sampaikan Schattschneider dkk (2004 dalam Santrock, 2009) bahwa kesadaran fonologi, nama huruf dan pengetahuan bunyi, serta kecepatan penamaan di taman kanak-kanak dikaitkan dengan sukses membaca di kelas pertama dan ke dua. Banyak anak-anak di TK mengembangkan kesadaran fonologi dengan baik. Beberapa terlihat untuk pengembangan kemampuan yang cukup mudah dalam stimulasi lingkungan di kelas, 
sementara yang lain membutuhkan lebih banyak intruksi secara sadar dan sengaja untuk fokus pada kesadaran fonologi.

Ketika anak menguasai kesadaran akan tulisan, kesadaran akan abjad dan kesadaran akan fonem maka anak telah memiliki suatu dasar yang kuat untuk mulai belajar membaca. Sebelum belajar membaca anak harus dapat membunyikan kata-kata yang tidak dikenal. Untuk itu kesadaran fonologis merupakan langkah awal dalam belajar membaca bagi anak-anak prasekolah yang akan memasuki jenjang selanjutnya.

Kesadaran fonologi pada dasarnya mengkaji dua paparan, yakni pada level dan komponen kesadaran fonemik itu sendiri (Yopp \& Yopp, 2009). Level kesadaran fonologi anak terdiri dari kata, suku kata, onset-rime dan bunyi. 1) kata yaitu kumpulan bunyi ujaran atau huruf yang mengandung satu arti yang jelas. Misalkan, kumpulan bunyi dari huruf /r-u-m-a-h/ = /rumah/, 2) suku kata adalah penggalan-penggalan bunyi dari kata dalam satu ketukan atau satu hembusan nafas. Kata /rumah/ akan diucapkan /ru-mah/, kata /berenang/ akan diucapkan /bə-rə-nay/, 3) onsetrime, onset yaitu bunyi konsonan yang mendahului vokal dalam suku kata (bunyi yang awalan-nya sama) sedangkan rime yaitu bunyi yang terdiri dari vokal dan beberapa bunyi yang mengikuti suku kata (bunyi yang akhiran-nya sama). Misalkan, terdapat tiga kata: /rusa/, /lima/ dan /rabu/ dari kata tersebut anak diminta untuk menentukan kata apa yang awalan bunyinya sama. Selanjutnya ada tiga kata: /pantai, /pisau/ dan /hijau/, anak diminta untuk menentukan kata yang akhiran bunyi-nya sama. Sedangkan fonemik merupakan unit terkecil dari kata.

Kesadaran fonologi anak akan lebih baik jika didukung berbagai aktivitas bahasa. Anak-anak mempunyai kecenderungan yang natural untuk bermain dan mengoptimalkan waktu agar dapat membantu perkembangan dan memperluas eksplorasi mereka. Guru di kelas secara sengaja harus dapat membentuk lingkungan yang kaya akan fonologi sama halnya dengan pemberian lingkungan yang kaya akan cetak (Torgessen \& Mathes, 1998, diacu dalam Yopp \& Yopp, 2009). Anak-anak belajar tentang sesuatu yang baru dan ketika mereka melihat hal tersebut mereka gunakan ke berbagai konteks dan berbagai tujuan. Selain itu, anak mendapat manfaat dari lingkungan yang kaya akan bunyi bahasa, seperti bernyanyi, mendengarkan cerita dari buku, bermain kata, membaca sajak yang focus pada manipulasi bunyi dan lainlain. Beberapa aktivitas bahasa di atas, dapat mengembangkan kesadaran fonologi baik kata, suku kata, onsetrime dan bunyi. Guru dapat mendorong anak dalam berbagai aktivitas untuk mendapatkan target yang berbeda level pada kesadaran fonologi, merencanakan pengalaman yang dapat meningkatkan target dari unit bunyi terbesar ke yang paling kecil, dan menciptakan bunyi pada tipe yang dimanipulasi.

Berdasarkan pemaparan tersebut, penelitian ini bertujuan untuk menganalisis kesadaran fonologi anak berdasarkan level kesadaran fonologi, yaitu kata, suku kata, dan onset-rime. Penelitian ini juga mengidentifikasi ragam aktivitas yang dilakukan oleh guru dalam mendukung kesadaran fonologi anak.

\section{METODE}


Penelitian ini merupakan penelitian deskriptif dengan pendekatan naturalistik yang bertujuan untuk menggali dan mendeskripsikan kesadaran fonologi pada anak usia prasekolah. Kegiatan penelitian dilakukan pada bulan Agustus sampai dengan bulan November tahun 2016. Lokasi penelitian dipilih secara purposive yaitu di salah satu Taman Kanak-Kanak yang ada di Kota Jambi, Provinsi Jambi.

Populasi dalam penelitian ini adalah seluruh siswa di Taman KanakKanak yang menjadi lokasi penelitian. Pengelompokan siswa di sekolah ini berdasarkan usia anak. Salah satu syarat yang harus dipenuhi dalam penelitian ini adalah kelas yang menjadi subjek penelitian adalah kelas yang terdiri atas anak yang berusia 5-6 tahun. Berdasarkan kriteria tersebut, ada tujuh kelas yang memenuhi kriteria dan dapat menjadi subjek penelitian. Selanjutnya, peneliti memilih satu kelas secara acak. Subjek dari penelitian ini adalah siswa dan guru dari kelas terpilih. Kelas yang terpilih terdiri atas 1 orang guru dan 19 orang siswa. Akan tetapi, 4 orang siswa tidak mengikuti secara lengkap seluruh rangkaian kegiatan penelitian. Dengan demikian, data yang dapat diolah adalah data dari 15 orang siswa saja.

Data yang dikumpulkan dalam penelitian ini adalah data primer yaitu kesadaran fonologi anak dan identifikasi ragam aktivitas yang mendukung kesadaran fonologi anak. Kesadaran fonologi anak dikumpulkan dengan cara unjuk kerja. Unjuk kerja adalah penilaian yang menuntut anak untuk melakukan tugas dalam perbuatan yang dapat diamati. Unjuk kerja dilakukan dengan memberikan penugasan pada anak sebanyak tiga kali penugasan. Unjuk kerja yang dilakukan terdiri atas empat level kesadaran fonologi, yaitu pada level kata, suku kata, onset, dan rime. ragam aktivitas yang mendukung kesadaran fonologi anak dikumpulkan dengan cara observasi kegiatan pembelajaran di kelas dan wawancara dengan guru. Data yang telah dikumpulkan diolah dan dianalisis secara deskriptif.

\section{HASIL DAN PEMBAHASAN \\ Kesadaran Fonologi Anak Berdasarkan Unjuk Kerja I}

Sebaran kesadaran fonologi anak berdasarkan hasil unjuk kerja I disajikan pada Tabel 1.

Tabel 1 Distribusi frekuensi kesadaran fonologi anak pada unjuk kerja I

\begin{tabular}{|c|c|c|c|c|c|c|c|c|c|c|c|c|c|c|c|c|c|}
\hline \multirow[t]{2}{*}{ Level } & \multicolumn{15}{|c|}{ Nama Anak } & \multicolumn{2}{|c|}{ Frekuensi } \\
\hline & MF & FA & $\mathrm{LH}$ & VS & AQ & TK & AR & $\mathrm{CG}$ & KJ & AP & DD & DA & RF & $\mathrm{AD}$ & MR & $\mathrm{n}$ & $\%$ \\
\hline Kata & 1 & 1 & 0 & 1 & 1 & 1 & 1 & 0 & 1 & 1 & 1 & 1 & 1 & 1 & 1 & 13 & 87 \\
\hline Suku kata & 0 & 0 & 0 & 0 & 1 & 1 & 0 & 0 & 0 & 1 & 1 & 0 & 1 & 0 & 1 & 6 & 40 \\
\hline Onset & 1 & 1 & 1 & 1 & 1 & 1 & 0 & 1 & 1 & 1 & 0 & 1 & 1 & 0 & 1 & 12 & 80 \\
\hline Rime & 0 & 0 & 0 & 0 & 0 & 1 & 0 & 1 & 0 & 1 & 0 & 0 & 0 & 0 & 0 & 3 & 20 \\
\hline
\end{tabular}

Pada level kata (Unjuk Kerja I), anak diminta untuk membunyikan kata dalam kalimat /apəl-bulat-merah/. Hasil penelitian yang disajikan pada Tabel 1 menunjukkan bahwa anak yang mampu membunyikan kata dalam kalimat tersebut dengan benar sebanyak 13 orang anak $(87 \%)$ dan anak yang belum mampu membunyikan kata tersebut dengan benar berjumlah 2 orang anak (13\%). Anak yang masih belum muncul kesadaran kata yaitu LH dan CG. LH membunyikan kata /apəl/ dengan benar begitu pula bunyi kata /merah/ sedangkan bunyi kata /bulat/ di ucapkan menjadi /bulét/. Selanjutnya, CG dapat membunyikan kata /apel/. 
Namun pada kata /bulat/, CG membunyikan /bulət/, /bu-la?, sedangkan kata /merah/, CG membunyikannya dengan /me-ra?/ Hasil ini memperlihatkan bahwa CG kesulitan untuk mengucapkan bunyi /r/.

Pada level suku kata (Unjuk Kerja I), anak diminta untuk membunyikan suku kata dari kata /kəlinci/=/kə-lin-ci/. Hasil penelitian yang disajikan pada Tabel 1 menunjukkan bahwa anak yang mampu membunyikan suku kata dengan benar berjumlah 6 orang (40\%). Hasil ini mengindikasikan bahwa sebagian besar anak belum mampu membunyikan suku kata dengan benar. Ketika anak diminta membunyikan suku kata dari kata $\quad /$ kəlinci/=/ko-lin-ci/, anak membunyikan suku kata tersebut dengan pola yang tidak benar yaitu /kəli-nci/.

Level onset-rime (Unjuk Kerja I), anak diminta untuk mendeteksi bunyi awal yang sama (onset) pada kata /anjin/, /buku/ dan /apəl/ dan anak juga diminta untuk mendeteksi bunyi akhir yang sama pada kata /anjin/, /bom/dan /pisay/. Hasil penelitian yang disajikan pada Tabel 1 menunjukkan bahwa anak yang mampu mendeteksi bunyi kata yang awalannya sama dengan benar berjumlah 12 orang anak (80\%) dan anak anak yang mampu mendeteksi bunyi kata yang awalannya sama berjumlah 3 orang anak (20\%). Hasil ini mengindikasikan bahwa sebagian besar anak mampu membedakan bunyi dengan awalan yang sama. Sementara itu, sebagian besar anak mengalami masalah dalam hal mendeteksi bunyi dengan akhiran yang sama. Hasil penelitian yang disajikan pada Tabel 1 menunjukkan bahwa anak yang mampu mendeteksi bunyi dengan akhiran yang sama dengan benar berjumlah 3 orang anak (20\%) dan anak yang belum mampu mendeteksi bunyi dengan akhiran yang sama dengan benar berjumlah 12 orang anak $(80 \%)$. Ketidakmampuan anak dalam mendeteksi bunyi dengan akhir yang sama disebabkan oleh kosentrasi anak yang kurang terhadap bunyi yang dituju.

\section{Kesadaran Fonologi Anak Berdasarkan Unjuk Kerja II}

Sebaran kesadaran fonologi anak berdasarkan hasil unjuk kerja II disajikan pada Tabel 2.

Tabel 2 Distribusi frekuensi kesadaran fonologi anak pada unjuk kerja II

\begin{tabular}{|c|c|c|c|c|c|c|c|c|c|c|c|c|c|c|c|c|c|}
\hline \multirow{2}{*}{ Level } & \multicolumn{15}{|c|}{ Nama Anak } & \multicolumn{2}{|c|}{ Frekuensi } \\
\hline & MF & FA & $\mathrm{LH}$ & VS & AQ & TK & AR & $\mathrm{CG}$ & KJ & AP & DD & DA & RF & $\mathrm{AD}$ & MR & $\mathrm{n}$ & $\%$ \\
\hline Kata & 1 & 1 & 1 & 1 & 1 & 1 & 1 & 0 & 1 & 1 & 1 & 1 & 1 & 1 & 1 & 14 & 93 \\
\hline Suku kata & 0 & 1 & 0 & 0 & 1 & 1 & 1 & 0 & 1 & 1 & 1 & 0 & 1 & 1 & 1 & 10 & 67 \\
\hline Onset & 1 & 1 & 1 & 1 & 1 & 1 & 0 & 1 & 1 & 1 & 1 & 1 & 1 & 0 & 1 & 13 & 87 \\
\hline Rime & 1 & 0 & 0 & 1 & 0 & 1 & 0 & 1 & 0 & 1 & 0 & 1 & 1 & 1 & 0 & 8 & 53 \\
\hline
\end{tabular}

Pada level kata (Unjuk Kerja II), anak diminta untuk membunyikan kata dalam kalimat /mつǹct-makanpisay/. Hasil penelitian yang disajikan pada Tabel 2 menunjukkan bahwa anak yang mampu membunyikan kata dalam kalimat tersebut dengan benar sebanyak 14 orang anak (93\%) dan anak yang belum mampu membunyikan kata tersebut dengan benar berjumlah 1 orang anak (7\%). Anak yang masih belum muncul kesadaran kata yaitu CG.

Pada level suku kata (Unjuk Kerja II), anak diminta untuk membunyikan suku kata dari kata /delapan/ = /də-la-pan/. Hasil penelitian yang disajikan pada Tabel 2 menunjukkan bahwa anak yang mampu membunyikan suku kata dengan benar 
berjumlah 10 orang $(67 \%)$. Hasil penelitian juga menunjukkan bahwa terdapat 5 orang anak (33\%) yang belum mampu membunyikan suku kata dari kata /delapan/ dengan benar. Kesalahan yang dilakukan anak adalah kesalahan penyebutan. Ada anak yang menyebutkan suku kata dari kata /delapan/ menjadi /də-la-tam/. Selain itu, penelitian ini juga menemukan anak yang tidak mampu menyebutkan suku kata, sebaliknya anak menjadi berhitung (delapan, Sembilan, sepuluh).

Level onset-rime (Unjuk Kerja II), anak diminta untuk mendeteksi bunyi awal yang sama pada kata /topi/, /sapu/ dan /tas/ dan anak juga diminta untuk mendeteksi bunyi akhir yang sama pada kata /sapi/, /topi/ dan /tas/. Hasil penelitian yang disajikan pada Tabel 2 menunjukkan bahwa anak yang mampu mendeteksi bunyi kata yang awalannya sama dengan benar berjumlah 13 orang anak (87\%).

Penelitian ini juga menemukan bahwa masih terdapat anak yang belum mampu mendeteksi bunyi dengan awalan yang sama yaitu AR dan AD. Kedua anak ini menjawab bahwa yang bunyi awalan yang sama dari kata /tas/ adalah /sapu/ kemungkinan jawaban mereka karena si anak fokus pada bunyi /s/ pada kata /tas/ seharusnya yang dilihat adalah bunyi /t/ pada kata /tas/ bukan /s/ pada kata /tas/. Selanjutnya, penelitian ini masih menemukan bahwa nak masih mengalami kesulitan dalam mendeteksi bunyi dengan akhiran yang sama pada unjuk kerja II. Hasil penelitian pada Tabel 2 menunjukkan bahwa anak yang mampu mendeteksi bunyi akhiran yang sama pada kata /sapi/, /topi/ dan /tas/ berjumlah 8 orang anak (53\%).

\section{Kesadaran Fonologi Anak Berdasarkan Unjuk Kerja III}

Sebaran kesadaran fonologi anak berdasarkan hasil unjuk kerja III disajikan pada Tabel 3.

Tabel 3 Distribusi frekuensi kesadaran fonologi anak pada unjuk kerja III

\begin{tabular}{|c|c|c|c|c|c|c|c|c|c|c|c|c|c|c|c|c|c|}
\hline \multirow{2}{*}{ Level } & \multicolumn{15}{|c|}{ Nama Anak } & \multicolumn{2}{|c|}{ Frekuensi } \\
\hline & MF & FA & LH & VS & $\mathrm{AQ}$ & TK & AR & CG & KJ & AP & DD & DA & $\mathrm{RF}$ & $\mathrm{AD}$ & MR & $\mathrm{n}$ & $\%$ \\
\hline Kata & 1 & 1 & 1 & 1 & 1 & 1 & 1 & 0 & 1 & 1 & 1 & 1 & 1 & 1 & 1 & 14 & 93 \\
\hline $\begin{array}{l}\text { Suku } \\
\text { kata }\end{array}$ & 0 & 1 & 0 & 0 & 1 & 1 & 1 & 0 & 1 & 0 & 0 & 0 & 1 & 1 & 0 & 8 & 53 \\
\hline Onset & 1 & 1 & 1 & 1 & 1 & 1 & 0 & 0 & 1 & 1 & 1 & 1 & 1 & 0 & 1 & 12 & 80 \\
\hline Rime & 1 & 0 & 0 & 1 & 0 & 1 & 0 & 1 & 0 & 1 & 0 & 1 & 1 & 0 & 0 & 7 & 47 \\
\hline
\end{tabular}

Pada level kata (Unjuk Kerja III), anak diminta untuk membunyikan kata dalam kalimat /pOt-buya-mawar/. Hasil penelitian yang disajikan pada Tabel 3 menunjukkan bahwa anak yang mampu membunyikan kata dalam kalimat /pOt-buya-mawar/ dengan benar berjumlah 14 orang anak $(93 \%)$ dan anak yang mampu membunyikan kata dalam kalimat /pOt-buna-mawar/ dengan benar berjumlah 1 orang anak (7\%). Anak yang mengalami kesulitan dalam membunyikan kata tersebut adalah CG. CG yang membunyikan kata /pDt/ menjadi /tOt/.

Pada level suku kata (Unjuk Kerja III), anak diminta untuk membunyikan suku kata dari kata /səgitiga/ = /sə-gi-ti-ga/. Hasil penelitian yang disajikan pada Tabel 3 menunjukkan bahwa anak yang mampu membunyikan suku kata dari kata /səgitiga/ dengan benar berjumlah 8 orang anak (53\%) dan anak yang belum mampu membunyikan suku kata dari kata /səgitiga/ dengan benar berjumlah 7 orang anak (47\%). Anak 
yang mengalami kesulitan dalam menyebutkan suku kata dari kata tersebut adalah LH, CG dan AP. LH membunyikan suku kata yaitu /sə?-tiga/, /sə-ri/, /sə?-li/. AP selalu membunyikannya dengan /sə?-ti?/ dan CG juga membunyikan /səgitiga/ yaitu /si/ dan /sə-ti?-ga/.

\section{Pada level onset-rime (Unjuk}

Kerja III), anak diminta untuk mendeteksi bunyi awal yang sama pada kata /bebe?/, /sapi/ dan /sapu/ dan anak diminta untuk mendeteksi bunyi akhir yang sama pada kata /buku/, /sapu/ dan /bis/. Hasil penelitian yang disajikan pada Tabel 3 menunjukkan bahwa anak yang mampu mendeteksi bunyi kata yang awalannya sama dengan benar yaitu ada 12 orang anak (80\%) dan anak yang belum mampu mendeteksi bunyi dengan awalan yang sama berjumlah 3 orang anak (20\%). Anak yang mengalami kesulitan dalam menyebutkan bunyi kata dengan awalann yang sama adalah AR, AD, dan CG. Ketiga anak ini hampir menjawab bahwa antara /sapi/, /sapu/, dan /bebe?/ yang awalannya sama yaitu /sapi/ dan /bebek dari ekspresi yang timbul tampak bahwa ketiga anak menjawab tanpa adanya konsentrasi dan hanya menjawab tanpa merasakan Tabel 4 Hasil unjuk kerja kesadaran fon onset-rime

\begin{tabular}{|c|l|c|c|c|}
\hline \multirow{2}{*}{ No } & \multirow{2}{*}{ Level } & \multicolumn{3}{|c|}{ Hasil Unjuk Kerja (\%) } \\
\cline { 3 - 5 } & & I & II & III \\
\hline 1 & Kata & $87 \%$ & $93 \%$ & $93 \%$ \\
\hline 2 & Suku Kata & $40 \%$ & $67 \%$ & $53 \%$ \\
\hline 3 & Onset & $80 \%$ & $87 \%$ & $80 \%$ \\
\hline 4 & Rime & $20 \%$ & $53 \%$ & $47 \%$ \\
\hline
\end{tabular}

Keterangan: Merah $\leq 60 \%$; Biru $\geq 60 \%$

Bahasa yang digunakan oleh anak dalam penelitian ini adalah Bahasa Indonesia. Bahasa Indonesia memiliki karakteristik yang berbeda apabila dibandingkan dengan Bahasa dan berpikir perbedaan bunyi tersebut. Data berikut anak yang mampu mendeteksi bunyi kata yang akhirannya sama (rime) dengan benar yaitu berjumlah 7 orang anak $(43 \%)$ dan anak yang belum mampu mendeteksi bunyi dengan akhiran yang sama berjumlah 8 orang anak (53\%).

\section{Level Kesadaran Fonologi Anak Berdasarkan Hasil Unjuk Kerja}

Hasil penelitian memperlihatkan bahwa kesadaran fonologi tergambar pada level kata, suku kata dan onsetrime. Secara umum, kesadaran fonologi anak yang paling muncul di kelas lebih mengacu kepada level kata. Hasil unjuk kerja anak menunjukkan bahwa kesadaran fonologi anak yang paling tinggi $\geq 60 \%$ adalah yaitu pada level kata dan onset. Berbeda dengan pengamatan unjuk kerja suku kata dan rime yang hanya memiliki persentase $\leq$ $60 \%$. Berdasarkan pengamatan unjuk kerja I-III terdeteksi bahwa rime mempunyai persentase yang lebih kecil dari pada suku kata. Jadi, tingkatan level kesadaran fonologi anak di lokasi penelitian adalah kesadaran pada kata $\rightarrow$ onset $\rightarrow$ suku kata $\rightarrow$ rime. Hasil unjuk kerja kesadaran fonologi subjek penelitian pada level kata, suku kata, dan onset-rime disajikan pada Tabel 4 . 
Widjaja dan Winskel (2005) menunjukkan bahwa kesalahan membaca yang dilakukan oleh pembaca pemula dengan menggunakan Bahasa Inggris terletak pada membaca kata secara keseluruhan atau strategi keseluruhan kata (lexical strategy). Sementara itu, menurut Widjaja dan Winskel (2007), kesalahan yang dilakukan oleh anak yang menggunakan Bahasa Indonesia terletak pada korespondensi grafem dan fonem (sublexical strategy). Hasil yang sama juga ditemukan dalam penelitian ini. Dalam membunyikan kata, kesalahan yang dilakukan anak tidak mengacu pada keseluruhan bunyi kata tetapi kesalahan yang dilakukan hanya pada salah satu bunyi saja. Contohnya, ketika anak diminta membunyikan kata /merah/ maka anak membunyikan /mera?/. Hasil ini mengindikasikan bahwa anak menggunakan strategi membaca subleksikal dari pada leksikal. Dengan demikian, pendekatan yang dapat digunakan bagi pembaca pemula baik kata yang bermakna maupun tidak bermakna adalah lebih kepada pendekatan subleksikal dari pada leksikal.

\section{Ragam Aktivitas yang Mendukung Kesadaran Fonologi Anak}

Kesadaran fonologi menjadi salah satu faktor yang menentukan kesuksesan anak dalam membaca. Hasil wawancara dengan guru kelas menunjukkan bahwa guru masih belum akrab dengan istilah "kesadaran fonologi". Meskipun guru tidak mengenal istilah kesadaran fonologi, hasil observasi menunjukkan bahwa telah ada upaya yang dilakukan guru dalam kegiatan pembelajaran untuk mendukung kesadaran fonologi anak yaitu kesadaran fonologi pada level kata, suku kata, dan onset-rime.
Stimulasi yang diberikan guru untuk mendukung kesadaran fonologi anak adalah dengan menyediakan bahan ajar yang kaya akan cetak. Cara ini sesuai dengan pendapat Torgessen dan Mathes (1998), diacu dalam Yopp dan Yopp (2009) bahwa pemberian lingkungan yang kaya akan cetak merupakan salah satu upaya yang dapat dilakukan oleh guru untuk mendukung kesadaran fonologi anak. Guru telah menyediakan bahan ajar yang dapat mendukung kesadaran fonologi anak, akan tetapi jumlah dan jenis bahan ajar yang disediakan masih terbatas dan belum bervariasi. Keterbatasan media berdampak pada berkurangnya jumlah stimulasi yang dapat disediakan untuk anak (Hastuti, 2009). Keterbatasan jumlah dan ketidakberagaman bahan ajar yang tersedia juga berdampak pada aktivitas di kelas. Aktivitas di kelas menjadi tidak bervariasi dengan adanya masalah keterbatasan jumlah dan ketidakberagaman bahan ajar.

Selain dengan menyediakan media pembelajaran, sekolah juga mendukung kesadaran fonologi anak dengan melakukan aktivitas bahasa di kelas baik di dalam maupun di luar kelas. Aktivitas bahasa lebih dominan ditemukan pada aktivitas anak di dalam kelas. Aktivitas ini ditemukan pada saat anak melakukan kegiatan awal, kegiatan inti, dan kegiatan akhir. Pada kegiatan awal, aktivitas bahasa yang terlihat adalah guru mengajak anak untuk membaca pesan pagi, bernyanyi, dan berdo'a bersama. Menurut Adams, et al. (2013), membaca pesan pagi merupakan salah satu aktivitas bahasa yang dapat meningkatkan kesadaran fonologi anak. Selain itu, guru juga menyediakan lingkungan yang kaya akan bunyi bahasa, seperti bernyanyi, mendengarkan cerita dari buku, bermain kata, membaca sajak yang fokus pada manipulasi bunyi, dan lain- 
lain. Aktivitas ini juga merupakan bagian dari usaha guru unduk mendukung kesadaran fonologi anak, baik kata, suku kata, onset-rime dan bunyi.

Aktivitas bahasa lebih dominan terlihat pada sentra persiapan. Pada sentra persiapan, guru mengajarkan anak dalam mengidentifikasi huruf, menggabungkan huruf sehingga membentuk sebuah kata, menyusun kata sehingga membentuk kalimat sederhana, dan diakhiri dengan menulis dan membaca kata/kalimat sederhana yang telah disusun. Guru juga memberikan stimulasi untuk anak melalui aktivitas bahasa di luar kelas. Aktivitas bahasa yang ditemukan di luar kelas tidak sebanyak aktivitas bahasa yang di dalam kelas. Aktivitas bahasa yang terlihat ditemukan saat anak melakukan olahraga dan juga pementasan (bernyanyi, menari, membaca puisi, dan lain-lain). Pada saat ini, anak melakukan gerak, membunyikan kata, dan berekspresi.

Hasil pengamatan dan wawancara juga menunjukkan bahwa tidak tampak adanya aktivitas yang berkaitan dengan tepuk suku kata. Padahal, menurut Musfiroh (2009) tepuk suku kata adalah salah satu kegiatan yang dapat mendukung kesadaran fonologi anak. Phillips, Clancy-Menchetti, dan Lonigan (2008) juga mengemukakan hal yang sama bahwa menepuk dan mengetuk merupakan strategi yang menggunakan non verbal cues yang dapat digunakan untuk mendukung pemahaman anak. Ditemukan pula bahwa pergerakan fisik merupakan tindakan menempatkan bunyi bersama-sama atau mengambil bagian dari bunyi secara terpisah sehingga menjadi tambahan yang berguna selama tugas kata, suku kata dan bunyi. Suku kata adalah prinsip untuk menentukan kombinasi kata-kata yang monosilabis dan disilabis dalam sebuah bahasa. Suku kata sangatlah berperan penting bagi fonologis. Suku kata adalah hal yang paling baik dapat dipahami sebagai pembentukan konstituen dalam proses fonologis. Pendeknya pengertian tentang penyukuan sangat penting dalam pemahaman anak untuk menyusun sistem fonologis anak pada suatu bahasa. Dengan demikian, tepuk suku kata dapat digunakan untuk mendukung kesadaran fonologi anak. Oleh karenanya, guru diharapkan dapat menggunakan tepuk suku kata sebagai upaya dalam mendukung kesadaran fonologi anak.

Selain tepuk suku kata, kegiatan dalam mendeteksi bunyi awal dan akhir yang sama (onset dan rime) juga jarang ditemukan pada aktivitas di dalam kelas. Aktivitas ini hanya ditemukan pada saat waktu senggang, pada saat guru dan anak berdiskusi dan bercanda. Hal ini lah yang menjadi salah satu penyebab belum munculnya kesadaran anak dalam hal onset dan rime. Hasil ini didukung oleh Lane, et al. (2000), diacu dalam Dave (2013) bahwa level onset-rime sering dihilangkan dari pembelajaran membaca dini. Oleh karenanya, guru juga diharapkan juga menambah aktivitas bahasa terutama dalam hal kesadaran onset-rime.

\section{SIMPULAN}

Status kesadaran fonologi anak yang paling muncul adalah (1) kata, (2) onset, (3) suku kata, dan (4) rime. Anak mengalami kesulitan dalam membunyikan suku kata dan rime. Anak sering melakukan kesalahan ketika membaca atau membunyikan kata. Kesalahan yang dilakukan adalah bersifat sublexical atau pada fonologisnya bukan pada keseluruhan kata (lexical). Berdasarkan hasil penelitian, kesadaran fonologi anak 
masih belum optimal terutama pada level onset-rime. Oleh karenanya, lingkungan keluarga dan sekolah yang merupakan lingkungan terdekat dengan anak perlu untuk menambah stimulasi yang mampu mendorong kesadaran fonologi anak.

Istilah "kesadaran fonologi" masih belum akrab di kalangan guru. Meskipun demikian, guru telah melakukan beberapa upaya untuk mendukung kesadaran fonologi anak, diantaranya adalah penyediaan bahan ajar dan kegiatan kelas yang dapat mendukung kesadaran fonologi anak. Permasalahannya, jumlah dan jenis bahan ajar yang telah disediakan masih terbatas dan belum bervariasi. Keterbatasan jumlah dan ketidakberagaman bahan ajar yang tersedia juga juga berdampak pada tidak bervariasinya aktivitas di kelas. Oleh karenanya, guru perlu menambah pengetahuan mengenai upaya yang dapat dilakukan oleh guru dalam kegiatan pembelajaran untuk mendukung kesadaran fonologi anak mengingat kesadaran fonologi penting dalam kesuksesan anak dalam membaca.

\section{DAFTAR PUSTAKA}

Adams, dkk. (2013). Chapter 2: Phonological Comprehensive Awareness. Resource for Kindergarten Teachers. Tersedia di https://www. hand2mind. com /pdf/kindergarten/chapter2.pdf.

Ayriza, Y. (1997). Pelatihan Kesadaran Fonologis pada Anak-Anak Prasekolah untuk Menyambut Tugas Belajar Membaca pada Masa Sekolah. Cakrawala Pendidikan No 1. 153-171.

Dave, S. (2013). Development of Phonological Awareness for Preschool and
Kindergarten Students at Risk of Reading Failure. Thesis. Tersedia di http: //montessoriedmonton.com/wpcontent/uploads/2013/09/Phonolo gical Awareness-A Thesis by Surabhi Dave.pdf.

Hastuti, D. (2009). Stimulasi psikososial pada anak kelompok bermain dan pengaruhnya pada perkembangan motorik, kognitif, sosial emosi, dan moral/karakter anak. Jurnal Ilmu Keluarga \& Konsumen, 2(1), 41-56.

Musfiroh, T. (2009). Menumbuhkembangkan BacaTulis Anak Usia Dini. Jakarta: Grasindo, PT. Gramedia Widiasarana Indonesia.

Phillips, B.M., Clancy-Menchetti, J. \& Lonigan, C.J. (2008). Successful Phonological awareness Instruction With Preschool Children: Lesson From the Classroom. Topics in Early Childhood Special Education Journal. 28(1): 3-17. doi: 10.11770271121407313813.

Santrock, J.W. (2009). Child Development. Twelfth edition. New York, US: McGraw-Hill.

Widjaja, V \& Winskel, H. (2005). Phonological Awareness and Word Reading in a Transparent Ortography: Preliminary Findings on Indonesian. Proceedings of the 10th Australian International Conference on Speech Science \& Technology page 370-375.

Widjaja, V \& Winskel, H. (2007). Phonological Awareness, Letter Knowledge, and Literacy Development in Indonesian Beginner Readers and Spellers. Cambridge University Press.

Yopp, H.K, \& R.H, Yopp. (2009). Beyond the Journal. Young 
Children on the Web.

Phonological Awareness Is

Child's Play!. Tersedia di

http://www.naeyc.org/files

/yc/file/200901/BTJPhonological

Awareness.pdf, diakses pada

tanggal 11 November 2016. 